\title{
弾性平板上の進行波を利用した水中推進機の 推力向上のための反射波抑制手法
}

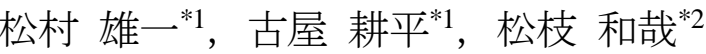 \\ 北山 弘樹*3，堀井 宏祐 ${ }^{* 4}$ ，安田 孝宏*5
}

\section{Suppression of reflected waves of an aquatic flexible plate to improve efficiency of an aquatic propulsion mechanism}

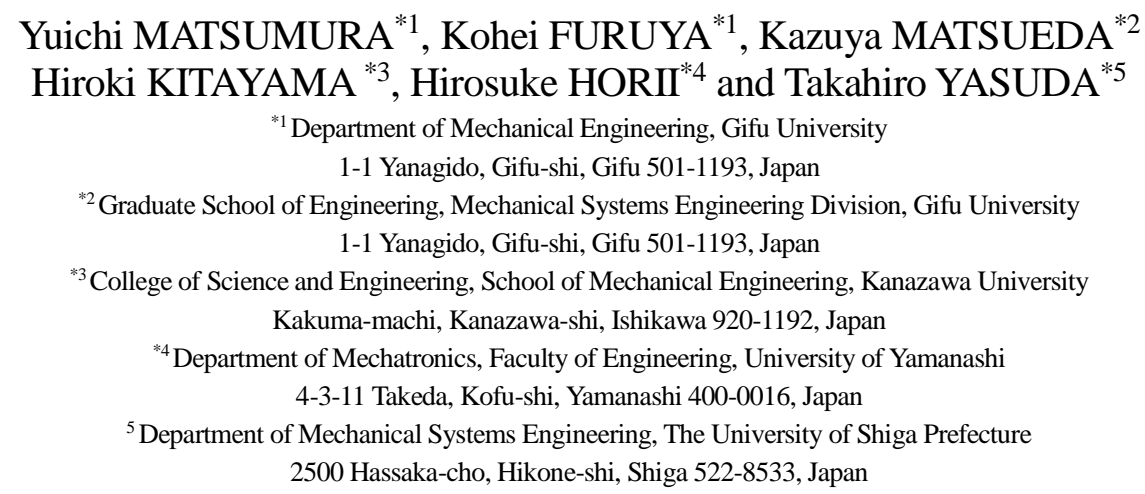

Received 29 January 2015

\begin{abstract}
This study deals with a generation method of undulatory motion of an aquatic flexible plate, to improve the efficiency of an aquatic propulsion mechanism by suppression of a reflection wave on a trailing edge. Firstly, non-reflection impedance of a flexible plate was derived by using a matrix-based wave approach, and then control forces for trailing edge of a plate was derived by the impedance. Secondly, obtained non-reflection impedance was translated into the relationship of the displacements between leading edge and trailing edge, to generate a pure traveling wave by three linear actuators. By the relationship, appropriate forced displacements of trailing edge are available by referring to driving signals. However, the method uses a wave number of an aquatic planar plate, which is dependent on added mass effect. To overcome this difficulty, an identification method of wave numbers with constant amplitude for various driving frequencies was introduced. Finally the method was applied to an experimental apparatus. Experimental results showed that a quasi-pure traveling wave was generated on an aquatic flexible plate by the method.
\end{abstract}

Key words : Wave, Vibration of continuous system, Active wave control, Bio-mimetics, Wave reflection

\section{1. 緒 言}

水棲生物の泳ぎに学び，スクリュープロペラよりも優れた水中推進機構を開発しようとする研究が行われてい

No.15-00060 [DOI:10.1299/transjsme.15-00060], J-STAGE Advance Publication date : 15 June, 2015

${ }^{*}$ 正員, 岐阜大学 工学部（产501-1193 岐阜県岐阜市柳戸 1-1）

*2 学生員, 岐阜大学 大学院 工学研究科

*3 正員, 金沢大学 理工研究域 機械工学系（广920-1192 石川県金沢市角間町）

*4 正員, 山梨大学 工学部 情報メカトロニクス工学科（†400-0016 山梨県甲府市武田 4-3-11）

*5 正員, 滋賀県立大学 工学部 機械システム工学科（テ522-8533 滋賀県彦根市八坂町 2500）

E-mail of corresponding author: y_matsu@gifu-u.ac.jp 
る（加藤，2001），（田中，永井，1996）。水棲生物の泳ぎ方は，魚体に進行波を送って推進するものや，尾ひれを 振動させて推進するものなど多様である（東，1997），(Sfakiotakis, et al., 1999）。これらの中で，魚体に進行波を 送って抵抗力で推進する泳法（神部，1978）を機械的に模擬した進行波型の水中推進方式は，例えば多リンク模 倣モデル（小林，1994）や，イカのヒレの進行波的運動を模擬した水中推進機構（戸田，2008）などでその有用 性が検討されてきた. しかし，これらの水中推進機構は，多数のアクチュエータを用意し，それらに位相差を与 えて進行波を生成する方式であり，機構が複雑になり，コストや保守性が課題である．形状記憶合金アクチュエ 一タなどの柔軟アクチュエータを利用して, シンプルな構造で進行波運動を生成しようとする研究(福田他, 1990),

（山野他，2014）も見られるが，人が乗船する船舶サイズでの利用を考えた場合には，瞬間加熱の実現などの課 題があると考えられる.

一方，進行波型の水中推進機構には，弾性平板の前端に直動アクチュエータを配置し，この並進調和外力によ って前端を振動させて曲げ進行波を送る方式もある.この機構は少数のアクチュエータとシンプルな機構で実現 できるほか, 回転運動を直線運動に変換する機構を併用すれば, ディーゼルエンジンなど大型の回転型アクチュ エータを駆動源として利用することも可能と考えられ，小型船舶の推進装置となり得る. 水中推進機構開発の先 駆者とされる Hertel ら（Hertel，1967）は本方式を採用し，実験船 TUB-TUB 号により高効率な推進が可能である ことを示した（田中，永井，1996）。ただし，弾性平板上に定在波が発生すると推進効率が低下することが，渡辺 らの研究（渡辺他，2001）で示されている. 有限長構造物において前端から後端へ波を送れば，この波は後端で 反射して逆向きの波となり，前端から定常的に送られてくる波と重畳して定在波成分を生成する．定在波成分は 推進力を生み出さず, 推進の抵抗にしかならないことから推進効率が低下する. 進行波型水中推進機構では, 船 舶の速度に応じて弾性平板上に生成する曲げ波の位相速度を調整して推力を制御する必要があるが，この位相速 度は駆動周波数に応じて決まる．ところが，渡辺らが示したように，特定の駆動周波数での波動重畳により定在 波が支配的になると，船舶の速度によっては推進力を得にくく，加速しにくい航行速度が存在することになる. 任意の駆動周波数で効率よく推進力を得るには, 進行波に占める定在波の比率を小さく寸る工夫が不可欠である.

本論文では，少数のアクチュエータで進行波型水中推進機を実現させるために，弾性平板の前端に直動アクチ ユエータを配置するだけでなく，後端にも直動アクチュエータを配置し，後端で生じる反射波を抑制して純粋な 進行波を生成, 維持する水中推進機を構築する。これにより，反射による後退進行波が原因で定在波が形成され てしまう場合などと比較して推力が向上することが期待される．初めに，弾性平板の前後端を強制変位で駆動す ることで弾性平板の後端で生じる反射波を抑制する理論を構築する．次に，この理論を検証するための実験装置 を製作し，反射波の抑制が可能で，純粋進行波を生成できることを検証する．空中に置かれた弾性平板を対象に した先行研究では, 反射波を抑制する制御手法が既に構築されている (Gabai and Bucher, 2009), (田中, 菊島, 1990). しかし, 水中に置かれた弾性平板では水の付加質量効果を考慮する必要がある. 付加質量効果は, 弾性平 板の駆動振幅や航行速度などに依存すると考えられる．本論文では駆動振幅を一定とし，船舶を固定した条件に おける水中実験を行い, 付加質量効果を含む形で, 駆動周波数に対する波数の変化を表す分散曲線を同定した. また，この波数に基づいた実験により，任意の駆動周波数で純粋な進行波が生成可能であることを確認する.

\section{2. 水中に置かれた弾性平板後端での無反射条件}

矩形の弾性平板上を，その長手方向に曲げ平面波が伝播する際に，平板端部で波動が反射しないという無反射 条件を導く，本論文では，矩形平板の長手方向に低周波の曲げ平面波を伝播させる場合を対象とするため，弾性 平板の曲げ振動を Euler-Bernoulli はりでモデル化して求める. 初めに, 有限長の弾性はりの無反射条件を導出す る. 次に, 水の付加質量効果が波数の変化にだけ影響すると仮定し, 水中弾性はりの端部における無反射条件を 明らかにする.

\section{$2 \cdot 1$ Euler-Bernoulli はりの波動解}

Euler-Bernoulli はりの仮定の下で無反射条件を導出する準備として，波動の行列解法（Mace，1984）に基づい て波動解を定義しておく. $x$ 軸に沿って横たわる無限長のはりの微小要素の運動方程式は, 位置 $x$, 時刻 $t$ におけ るたわみを $w(x, t)$, 線密度を $\rho A$, 曲げ剛性を $E I$ とすれば次式で表せる. 


$$
\rho A \frac{\partial^{2} w(x, t)}{\partial t^{2}}=-\frac{\partial^{2}}{\partial x^{2}}\left[E I \frac{\partial^{2} w(x, t)}{\partial x^{2}}\right]
$$

本式を満たす角振動数 $\omega$ の波動解は，曲げ波の波数 $k=\sqrt[4]{\rho A / E I} \sqrt{\omega}$ を用いて次のように表される.

$$
\begin{aligned}
& w(x, t)=W(x) e^{j \omega t}, \\
& W(x) \equiv\left(a e^{-j k x}+b e^{j k x}+a_{N} e^{-k x}+b_{N} e^{k x}\right),
\end{aligned}
$$

ここに $W(x)$ はたわみ振幅を表し， $j$ は虚数単位である．また，図 1 に示すように,$a ， b$ はそれぞれ $x$ の正方向に 進む伝播波（以下，前進伝播波）と $x$ の負方向に進む伝播波（以下，後退伝播波）の $x=0$ における振幅を表し， $a_{N}, b_{N}$ はそれぞれ前進近接波と後退近接波の $x=0$ における振幅である. 以下，位置 $x$ における前進伝播波と前進 近接波の振幅に関連した項を，次式のように前進波の複素振幅ベクトル $\boldsymbol{a}(x)$ で表す.

$$
\begin{aligned}
& \boldsymbol{a}(x)=\left\{\begin{array}{c}
a e^{-j k x} \\
a_{N} e^{-k x}
\end{array}\right\}=\left[\begin{array}{cc}
e^{-j k x} & 0 \\
0 & e^{-k x}
\end{array}\right]\left\{\begin{array}{c}
a \\
a_{N}
\end{array}\right\}=\boldsymbol{G}_{a}(x) \boldsymbol{a}(0), \\
& \boldsymbol{a}(0) \equiv\left\{\begin{array}{c}
a \\
a_{N}
\end{array}\right\}, \quad \boldsymbol{G}_{a}(x) \equiv\left[\begin{array}{cc}
e^{-j k x} & 0 \\
0 & e^{-k x}
\end{array}\right] .
\end{aligned}
$$

同様に後退波の複素振幅ベクトル $\boldsymbol{b}(x)$ を次式のように表す.

$$
\begin{aligned}
& \boldsymbol{b}(x)=\left\{\begin{array}{c}
b e^{j k x} \\
b_{N} e^{k x}
\end{array}\right\}=\left[\begin{array}{cc}
e^{j k x} & 0 \\
0 & e^{k x}
\end{array}\right]\left\{\begin{array}{c}
b \\
b_{N}
\end{array}\right\}=\boldsymbol{G}_{b}(x) \boldsymbol{b}(0), \\
& \boldsymbol{b}(0) \equiv\left\{\begin{array}{c}
b \\
b_{N}
\end{array}\right\}, \quad \boldsymbol{G}_{b}(x) \equiv\left[\begin{array}{cc}
e^{j k x} & 0 \\
0 & e^{k x}
\end{array}\right] .
\end{aligned}
$$

ここに, $\boldsymbol{G}_{a}(x), \boldsymbol{G}_{b}(x)$ は前進波と後退波の伝播に伴う複素振幅の変化を表す行列であり，伝播行列と呼ぶ. 式（3） から（5）より，はりのたわみ振幅 $W(x)$ は次式のように複素振幅ベクトルを用いて表せる.

$$
W(x)=\left\{\begin{array}{ll}
1 & 1
\end{array}\right\} \boldsymbol{a}(x)+\left\{\begin{array}{ll}
1 & 1
\end{array}\right\} \boldsymbol{b}(x)
$$

また Euler-Bernoulli はりの理論から, たわみ角の振幅 $\Theta(x)$, 曲げモーメントの振幅 $M(x)$, せん断力の振幅 $F(x)$ が 次式のように求まる。 なお, 以下では簡単のため, たわみ角の振幅 $\Theta(x)$ をたわみ角 $\Theta(x)$ と呼び，たわみ $W(x)$, 曲 げモーメント $M(x)$, せん断力 $F(x)$ なども同様に呼称する.

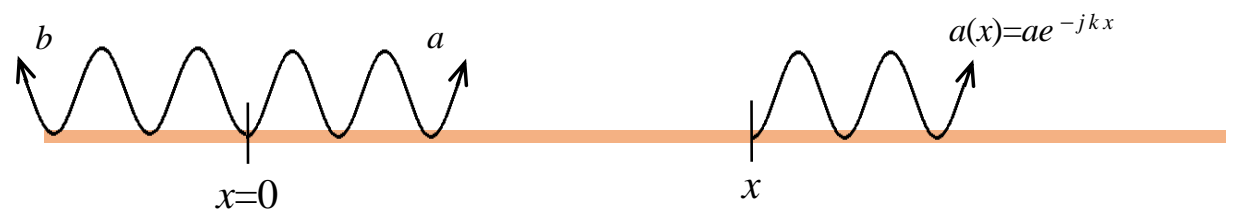

Fig. 1 Position-amplitude relation of a propagation wave. Here $a, b$ respectively indicate wave amplitude of a positive-going and a negative-going wave at the $x=0$. Wave amplitude at position $x$ is expressed in terms of multiplication of wave amplitude and propagation term e.g. positive-going wave amplitude at position $x: a(x)=a e^{-j k x}$. 


$$
\begin{aligned}
& \Theta(x)=\frac{\partial W(x)}{\partial x}=-j k a e^{-j k x}+j k b e^{j k x}-k a_{N} e^{-k x}+k b_{N} e^{k x} \\
& M(x)=E I \frac{\partial^{2} W(x)}{\partial x^{2}}=E I\left(-k^{2} a e^{-j k x}-k^{2} b e^{j k x}+k^{2} a_{N} e^{-k x}+k^{2} b_{N} e^{k x}\right) \\
& F(x)=-E I \frac{\partial^{3} w}{\partial x^{3}}=-E I\left(j k^{3} a e^{-j k x}-j k^{3} b e^{j k x}-k^{3} a_{N} e^{-k x}+k^{3} b_{N} e^{k x}\right)
\end{aligned}
$$

式（3）で表されるたわみ $W(x)$ と式（4）で表されるたわみ角 $\Theta(x)$ をまとめ，一般化変位ベクトル $\boldsymbol{W}(x)$ として定義 すると, 変位 $\boldsymbol{W}(x)$ と波動振幅 $\boldsymbol{a}(x), \boldsymbol{b}(x)$ の関係が次式で表せる.

$$
\boldsymbol{W}(x)=\left\{\begin{array}{l}
W(x) \\
\Theta(x)
\end{array}\right\}=\left[\begin{array}{cc}
1 & 1 \\
-j k & -k
\end{array}\right] \boldsymbol{a}(x)+\left[\begin{array}{cc}
1 & 1 \\
j k & k
\end{array}\right] \boldsymbol{b}(x) \equiv \boldsymbol{\Psi}_{a} \boldsymbol{a}(x)+\boldsymbol{\Psi}_{b} \boldsymbol{b}(x)
$$

ここに $\Psi_{a} ， \Psi_{b}$ は変位一波動振幅変換行列と呼ばれ，波数 $k$ だけに依存した行列である. また，式 (8), (9) から, せん断力 $F(x)$, 曲げモーメント $M(x)$ をまとめ, 一般化力ベクトル $\boldsymbol{F}(x)$ として定義すると, 力 $\boldsymbol{F}(x)$ と波動振幅 $\boldsymbol{a}(x)$, $\boldsymbol{b}(x)$ の関係が次式で表せる.

$$
\boldsymbol{F}(x)=\left\{\begin{array}{c}
F(x) \\
M(x)
\end{array}\right\}=E I\left[\begin{array}{cc}
-j k^{3} & k^{3} \\
-k^{2} & k^{2}
\end{array}\right] \boldsymbol{a}(x)+E I\left[\begin{array}{cc}
j k^{3} & -k^{3} \\
-k^{2} & k^{2}
\end{array}\right] \boldsymbol{b}(x) \equiv \boldsymbol{\Phi}_{a} \boldsymbol{a}(x)+\boldsymbol{\Phi}_{b} \boldsymbol{b}(x)
$$

ここに， $\boldsymbol{\Phi}_{a} ， \boldsymbol{\Phi}_{b}$ は力ー波動振幅変換行列と呼ばれ，波数 $k$ だけに依存した行列である.

\section{$2 \cdot 2$ 有限長はりの無反射条件の導出}

長さ $L$ の有限長はり上を前端 $x=0$ から送った波が $x=L$ の後端で反射しないために，はりの前端と後端のあるべ き変位の関係（無反射条件）を導出する. 有限長はりの前端 $x=0$ に力振幅 $F$ の並進駆動力だけが作用するとき, 前端の波動振幅 $\boldsymbol{a}(0), \boldsymbol{b}(0)$ は，式（11）から次式を満足する.

$$
\boldsymbol{\Phi}_{a} \boldsymbol{a}(0)+\boldsymbol{\Phi}_{b} \boldsymbol{b}(0)=\boldsymbol{F}(0)=\left\{\begin{array}{l}
F \\
0
\end{array}\right\}
$$

後端で波の反射が生じない場合，後退波の振幅は任意の位置 $x$ で $\boldsymbol{b}(x)=0$ であるので，本式は次式となる.

$$
\boldsymbol{\Phi}_{a} \boldsymbol{a}(0)=\left\{\begin{array}{l}
F \\
0
\end{array}\right\}
$$

また，反射が生じない場合の前端での一般化変位 $\boldsymbol{W}(0)$ は式（10)，（13）より次式で表される.

$$
\boldsymbol{W}(0)=\boldsymbol{\Psi}_{a} \boldsymbol{a}(0)=\boldsymbol{\Psi}_{a} \boldsymbol{\Phi}_{a}^{-1}\left\{\begin{array}{l}
F \\
0
\end{array}\right\}=\frac{1+j}{E I k^{3}}\left\{\frac{(-1-j) k}{2}\right\} F
$$

本論文では，位置サーボ制御による強制変位を，はりの前後端に与えて進行波生成を行うため，以下，式（14） の関係を用いて, 純粋進行波生成時の前端と後端の変位の関係式を求める. 式（14）より，前端部のたわみ角 $\Theta(0)$ 
は，前端部のたわみ $W(0)=(1+j) F /\left(E I k^{3}\right)$ に複素係数 $(-1-j) k / 2$ を乗じて表現できることがわかる．この複素 係数は, 複素指数関数に変形できることを利用寸れば，式（14）は次式に変形できる.

$$
\boldsymbol{W}(0)=\left\{\begin{array}{l}
W(0) \\
\Theta(0)
\end{array}\right\}=\left\{\begin{array}{l}
1 \\
\frac{\sqrt{2} k}{2} e^{-j \frac{3}{4} \pi}
\end{array}\right\} W(0)
$$

本式は，後端で波の反射が生じない場合の前端でのたわみ $W(0)$ とたわみ角 $\Theta(0)$ の関係を表している.この波動が 後端に到達するとき，後端 $x=L$ でのたわみ $W(L)$ とたわみ角 $\Theta(L)$ は式 $(4),(10)$ より次式で表される.

$$
\boldsymbol{W}(L)=\boldsymbol{\Psi}_{a} \boldsymbol{a}(L)=\boldsymbol{\Psi}_{a} \boldsymbol{G}_{a}(L) \boldsymbol{a}(0)
$$

また，式（14）より，前端 $x=0$ の振幅 $\boldsymbol{a}(0)$ は前端 $x=0$ でのたわみ $W(0)$ で次式のように表される.

$$
\boldsymbol{a}(0)=\boldsymbol{\Psi}_{a}^{-1} \boldsymbol{W}(0)
$$

よって, 式 $(15) \sim(17)$ から, 純粋進行波生成時の後端 $x=L$ における理想の一般化変位が次式のように求まる.

$$
\boldsymbol{W}(L)=\boldsymbol{\Psi}_{a} \boldsymbol{G}_{a}(L) \boldsymbol{\Psi}_{a}^{-1} \boldsymbol{W}(0)=\left[\begin{array}{cc}
1 & 1 \\
-j k & -k
\end{array}\right]\left[\begin{array}{cc}
e^{-j k L} & 0 \\
0 & e^{-k L}
\end{array}\right]\left[\begin{array}{cc}
1 & 1 \\
-j k & -k
\end{array}\right]^{-1}\left\{\frac{\sqrt{2} k}{2} e^{-j \frac{3}{4} \pi}\right\} W(0)
$$

実験では，式（15）の駆動点（はりの前端）たわみW(0)を，位置サーボ制御機構を利用した強制変位により与え るものとする. このとき，駆動点たわみ角 $\Theta(0)$ は式（15）から自動的に定まる. 一方，はりの後端には式（18） を満足するような強制変位を与える，この駆動法に従えば，反射波が抑制されて純䊀進行波が生成できる.

\section{$2 \cdot 3$ 水中に置かれた弾性平板の波数}

水中に置かれた弾性平板上を伝播寸る曲げ波の波数を第 4 章で実験的に同定するので，本節では，この同定に 必要となる関係式を導出しておく. 水中と空中のはりにおける波動伝播の差が波数だけにあると仮定すれば, 水 中に置かれた弾性はりの無反射条件は, 式（18）に水中での波数 $k$ を代入するだけで得られる.

水による付加質量効果が波数に与える影響を求める. 波の位相速度 $v$ と角振動数 $\omega$, 波数 $k$ の関係は $v=\omega / k$ である.一方, Euler-Bernoulli はりの曲げ波の波数は $k=\sqrt[4]{\rho A / E I} \sqrt{\omega}$ であり，位相速度 $v$ は次式で表せる.

$$
v(\omega)=\sqrt[4]{\frac{E I}{\rho A}} \sqrt{\omega}
$$

はりの断面が長方形で幅 $b$, 厚さ $h$ の場合, 位相速度 $v$ は次式となる.

$$
v(\omega)=\sqrt[4]{\frac{E}{\rho} \frac{b h^{3}}{12} \frac{1}{b h}} \sqrt{\omega}=\sqrt[4]{\frac{E}{12 \rho}} \sqrt{h} \sqrt{\omega}
$$

水中では, 構造物の加速度に比例した流体力により見かけ上構造物の質量が増加するような効果があり，これを 水の付加質量効果として密度増加 $\rho_{\mathrm{W}}$ で表すと, 水中に置かれた弾性はりの位相速度 $v_{\mathrm{W}}$ は次式で表せることがわ かる.

$$
v_{\mathrm{w}}(\omega)=\sqrt[4]{\frac{E}{12\left(\rho+\rho_{\mathrm{W}}\right)}} \sqrt{h} \sqrt{\omega}
$$


同様に水中に置かれた弾性はりの波数 $k_{\mathrm{w}}$ は次式で表される.

$$
\begin{aligned}
& k_{\mathrm{W}}(\omega)=\sqrt[4]{\frac{12\left(\rho+\rho_{\mathrm{W}}\right)}{E}} \frac{\sqrt{\omega}}{\sqrt{h}}=\beta_{\mathrm{W}} \sqrt{\omega} \\
& \beta_{\mathrm{W}} \equiv \sqrt[4]{\frac{12\left(\rho+\rho_{\mathrm{W}}\right)}{E}} \frac{1}{\sqrt{h}}
\end{aligned}
$$

式（21），(22）より，水中に置かれた弾性はりの位相速度は空中に置かれた場合と比較して小さくなり，波数は 大きくなることが予測される．また水中の波数 $k_{\mathrm{W}}$ は周波数に依存しない定数 $\beta_{\mathrm{W}}$ と周波数の平方根の積で表され る. 第 4 章では, 複数の周波数で波数 $k_{\mathrm{W}}(\omega)$ を計測し, その結果から式（23）の定数 $\beta_{\mathrm{W}}$ を同定する.

\section{3. 反射波抑制を検証するための実験装置}

\section{$3 \cdot 1$ 実験装置}

前章で説明した純粋進行波生成手法を検証するために構築した実験装置を説明する. 図 2(a)に実験装置の概略, 図 2(b)に実際の装置の写真，図 2(c)に弾性平板と双胴船の位置関係を示寸．はりとみなせる弾性平板は，地面に 固定した双胴船の左右船体の隙間に，水面に対して垂直に沈めた．双胴船は 3 次元形状のため，明確な寸法関係 は記載できないが, 船底から甲板までの深さは 200mm であり, 概略で図 2(c)に示寸位置に弾性平板は沈められて いる. 弾性平板の前端に進行波を生成するための駆動用リニアサーボアクチュエータ，後端には反射波を抑制す るためのリニアサーボアクチュエータ 2 台を配置している.弾性平板は, ばね用りん青銅 C5210 で, 寸法 $L=390 \mathrm{~mm}$, $b=40 \mathrm{~mm}, t=0.2 \mathrm{~mm}$ のものを利用した．アクチュエータと弾性平板の接続には，直径 $3 \mathrm{~mm}$ で長さ $300 \mathrm{~mm}$ のステ ンレス製の細い丸棒を使用し，この丸棒の柔軟性により $x$ 方向のたわみを許すことで平板の曲げに伴う長さの縮 小を許容している.リニアサーボアクチュエータは青山特殊鋼製 STA2506S を利用し，その指令電圧は dSPACE 社DS1104 から出力した．後端での反射を抑制し, 進行波のみを生成するため, 前端の変位 $W(0)$ を強制変位で与 えると同時に，変位 $W(L)$ および回転角 $\Theta(L)$ が式（18）を満たすように，後端にも強制変位を与えた.
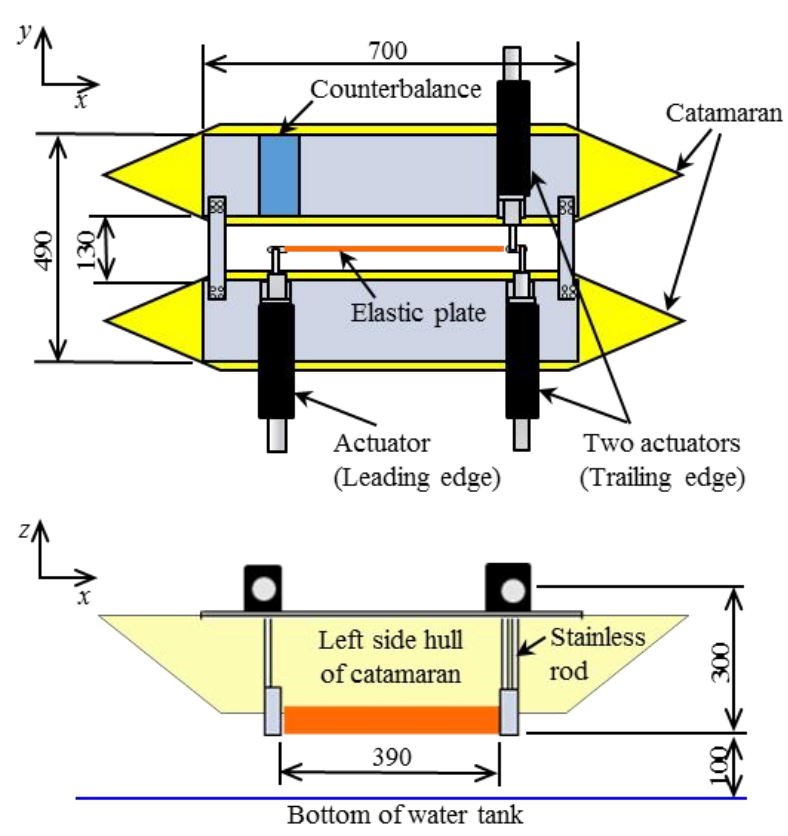

(a) Schematic drawing

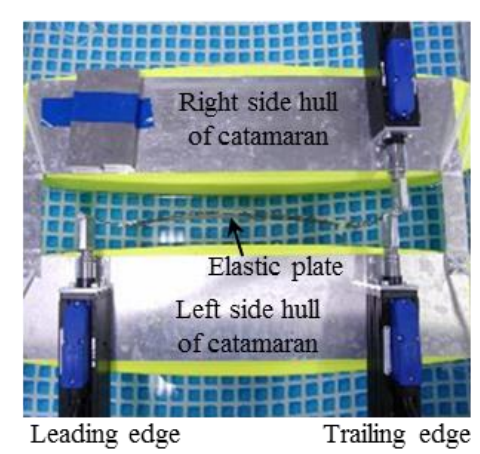

(b) Photograph

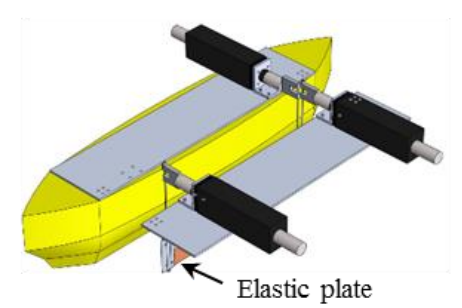

(c) Positional relation between the elastic plate and the hull of a catamaran

Fig. 2 Experimental apparatus to suppress reflected waves based on the non-reflection condition in chapter 2. The apparatus consists of flexible plate and three linear servo actuators. 


\section{$3 \cdot 2$ 弾性平板後端のたわみとたわみ角の制御}

平板後端のたわみ $W(L)$ とたわみ角 $\Theta(L)$ を 2 台のリニアサーボアクチュエータで与えるため, 図 3 に示すように, 後端に剛とみなせる板（以下，剛体板）を取り付けた．剛体板の 2 点の並進変位 $w_{1}, w_{2}$ を位置制御で与えること で，進行波生成に必要なたわみ $W(L)$ とたわ久角 $\Theta(L)$ を実現する．幾何学条件から次式が成り立つ.

$$
\begin{aligned}
& w_{1}+w_{2}=2 W(L) \\
& w_{2}-w_{1}=l \sin \Theta(L)
\end{aligned}
$$

式 (24)，（25）を $w_{1} ， w_{2}$ について解くと次式を得る.

$$
\left\{\begin{array}{l}
w_{1} \\
w_{2}
\end{array}\right\}=\left[\begin{array}{cc}
1 / 2 & 1 / 2 \\
l / 2 & -l / 2
\end{array}\right]^{-1}\left\{\begin{array}{c}
W(L) \\
\sin \Theta(L)
\end{array}\right\}=\left\{\begin{array}{l}
W(L)-l \sin \Theta(L) / 2 \\
W(L)+l \sin \Theta(L) / 2
\end{array}\right\}
$$

本式に, 弾性平板の無反射条件を満足する後端のたわみ $W(L)$, たわみ角 $\Theta(L)$ を代入して得られる变位 $w_{1}, w_{2}$ を, 実験装置の剛体板に与えることで，無反射条件を近似的に満足させる．実験装置では図 4 に示すように弾性平板 の長さ $L=390 \mathrm{~mm}$ に対して, 図 3 の $l=15 \mathrm{~mm}$ の剛体板を前後端に取り付けた.
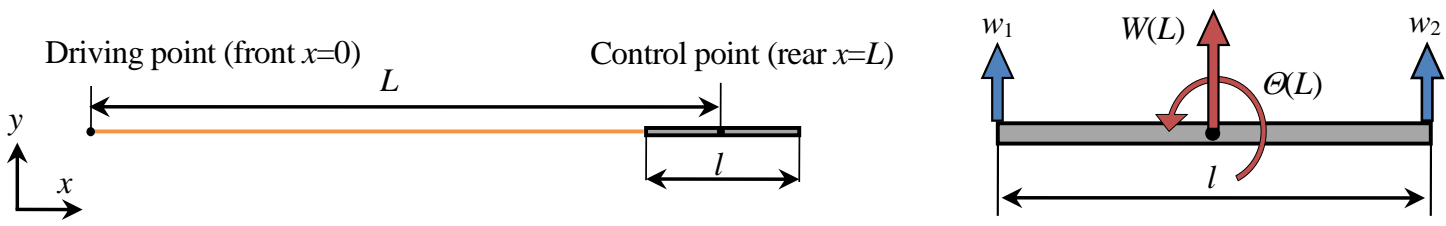

Fig. 3 Flexible plate with a rigid plate for trailing edge. To control the rotation angle $\Theta(L)$ at the trailing edge by two linear servo actuators, rigid plate is attached to the trailing edge of the plate. Desired displacement $W(L)$ and rotation angle $\Theta(L)$ are simultaneously realized by controlling the displacements $w_{1}$ and $w_{2}$.

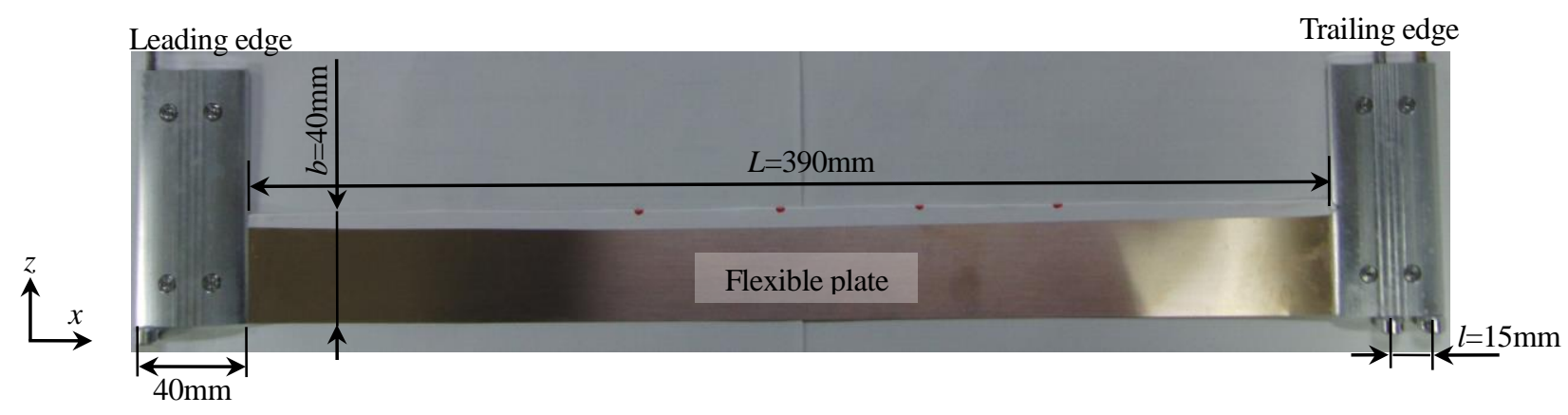

Fig. 4 Actual flexible plate with rigid plates $(l=15 \mathrm{~mm})$.

\section{4. 純粋進行波の生成}

\section{$4 \cdot 1$ 水中に置かれた弾性平板の波数の同定}

式（18）に従って純粋進行波を生成する方法を適用するため，以下で水中に置かれた弾性平板の波数を同定す る. 弾性平板の波数は式（22）に示したように周波数の平方根の関数で，その係数が定数 $\beta_{\mathrm{w}}$ で表される. 本節 では $0.5 \mathrm{~Hz}$ から $10 \mathrm{~Hz}$ の $0.5 \mathrm{~Hz}$ 刻みの駆動周波数で波数 $k_{\mathrm{w}}$ を求め，それらの值から定数 $\beta_{\mathrm{w}}$ を同定する. 具体的 には，水中に置かれた弾性平板上を伝播する波動の位相速度 $v$ を計測し，この位相速度 $v$ と波数 $k$ の関係式 $v=\omega$ $/ k$ を用いて，駆動周波数ごとの波数を求める．なお，位相速度は以下の手順で計測する. 
Matsumura, Furuya, Matsueda, Kitayama, Horii and Yasuda,

Transactions of the JSME (in Japanese), Vol.81, No.827 (2015)

(1) 図 5 に示すように, 弾性平板の前端付近に 4 点の計測点を設け, 高速度カメラで駆動中の弾性平板を撮影し, 画像解析で各計測点の変位を計測する，高速度カメラはCASIO EX-FH20 を利用し，撮影速度は210fps とす る.また，画像解析は Photron 社製の画像解析ソフトウェア TEMA で行う。

(2) 前端のアクチュエータのみを振幅 $15 \mathrm{~mm}$ で調和変位加振し, 最初に生成される波動の極值が計測点 1 から 4 までの各隣接点間を伝播する際に要する時間を求め, この区間での平均位相速度を求める.

この手順を $0.5 \mathrm{~Hz}$ から $10 \mathrm{~Hz}$ の $0.5 \mathrm{~Hz}$ 刻みで実施し, 位相速度と波数を求めて, 定数 $\beta_{\mathrm{w}}$ を同定する.一例として, $2 \mathrm{~Hz}$ で弾性平板を駆動した際の計測点 1 から 4 での変位の計測結果を図 6 に示寸. 本図において, ほぼ振幅 $15 \mathrm{~mm}$ で波動が伝播していることから,この波形のピーク位置の間隔から, 計測点間の伝播に要する時間が計測できる.

図 7 の分散曲線は，水中に置かれた弾性はりの波数の同定結果を示寸．赤丸は水中に置かれた弾性平板の波数 を示し, 赤線は式 (22) に従った波数の周波数依存性を仮定し, 各周波数の波数から最小二乗法で定数 $\beta_{\mathrm{w}}$ を求め た際の波数の周波数特性を示す. また, 青線は水の付加質量効果がない場合の波数であり, 式 (22) において $\rho_{\mathrm{w}}=0$ とおき，ば社用りん青銅の材料物性だけを与えることで求まる. 同定した水中弾性はりの波数 $k_{\mathrm{w}}$ と，空中の弾性 はりの波数 $k$ を比較すると, 水中弹性はりの波数の方が 2 倍程度も大きい. これは付加質量効果による影響と考 えられ，水中に置かれた弾性はりでの進行波生成には，付加質量効果を考慮する必要があることがわかる.

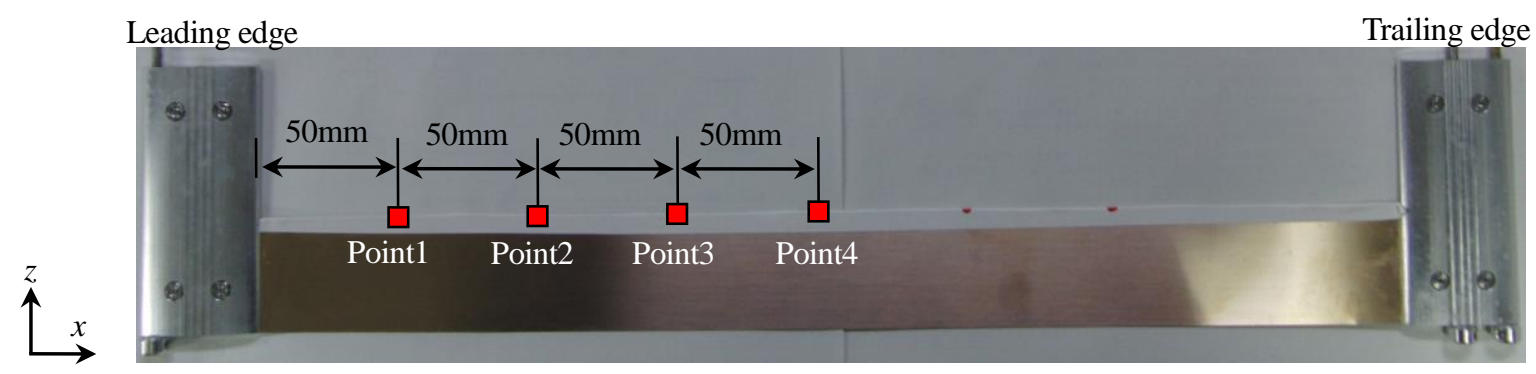

Fig. 5 Measurement points on the flexible plate for wave number identification. Displacements at four points are measured by digital image analysis. The image is taken by high speed digital camera (210fps).

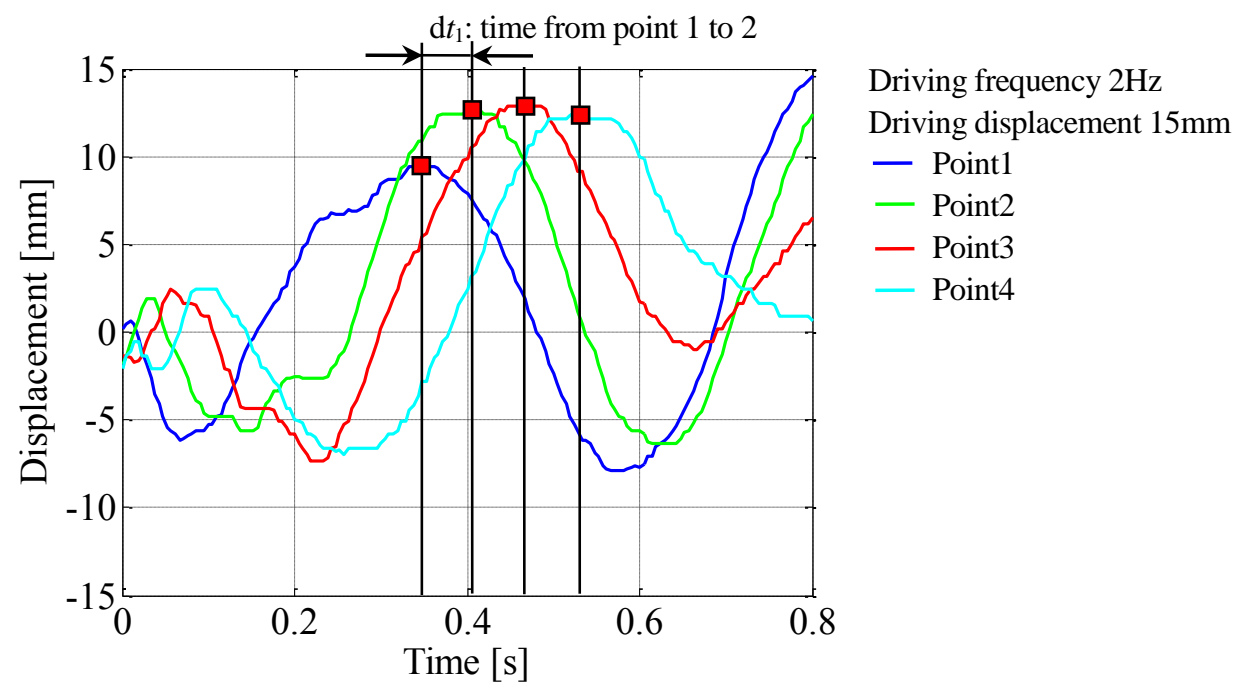

Fig. 6 Displacements at four measurement points. In the wave number identification, propagation delay d $t$ between two measurement points is measured, and phase velocity $v_{\mathrm{W}}$ is estimated by the delay. Finally, wave number of aquatic flexible plate $k_{\mathrm{W}}$ is calculated. 
Matsumura, Furuya, Matsueda, Kitayama, Horii and Yasuda,

Transactions of the JSME (in Japanese), Vol.81, No.827 (2015)

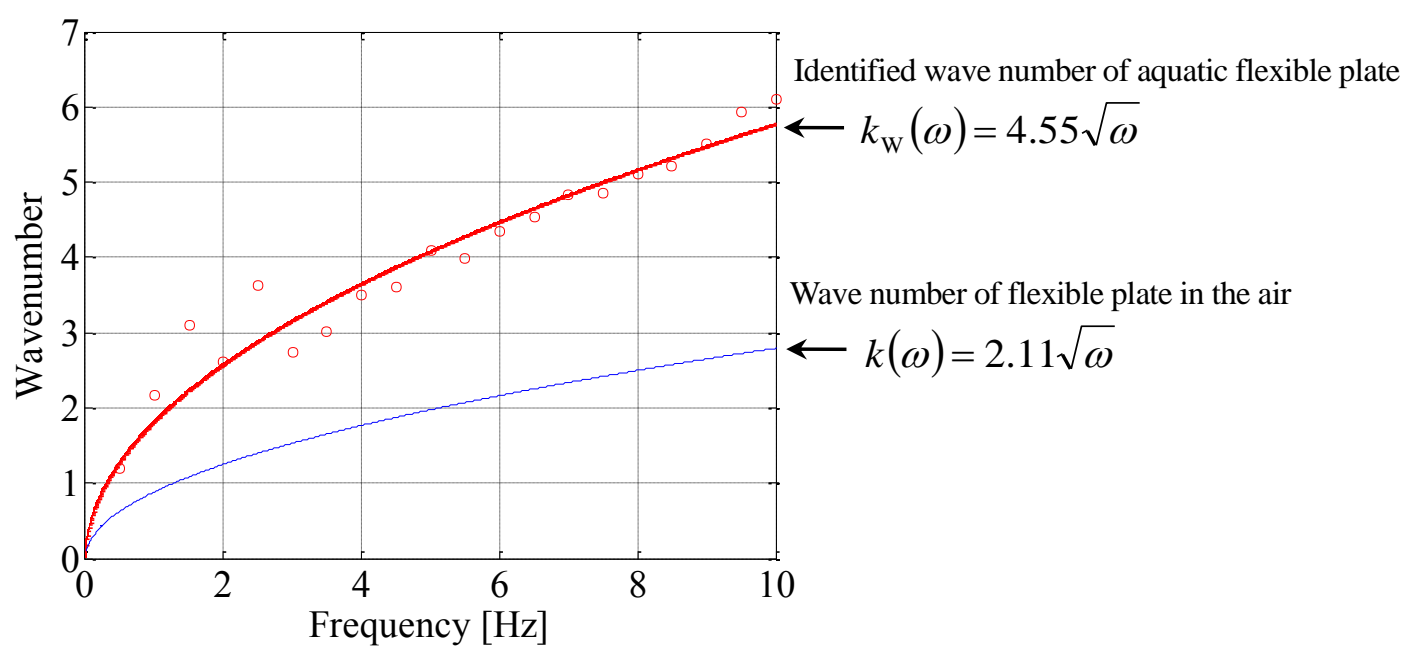

Fig. 7 Identified wave number of the aquatic flexible plate, and wave number of the plate in the air, for comparison. Wave number of the aquatic flexible plate is identified from the phase velocities.

\section{4-2 純粋進行波の生成実験}

式（18）に示す駆動方法と，水中の弾性平板の挙動から同定された波数を利用し，後端での反射が生じず，純 粋進行波が生成されるように，前端と後端のアクチュエータを，式（26）を参考にして変位制御する. 本実験で は，前端のアクチュエータのたわみ振幅 $W(0) を ，$ 波数同定時と同じ $15 \mathrm{~mm}$ とした．また，反射波が抑制され，純 粋進行波が生成されていることを定量的に検証するため，波動に含まれる進行波の振幅 $a$ と後退波（反射波）の 振幅 $b$ の割合を表す定在波比（SWR : Standing Wave Ratio）を求める.

$$
\operatorname{SWR}=\frac{|a|+|b|}{\| a|-| b||}
$$

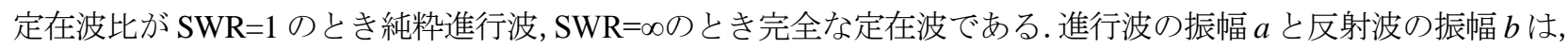
駆動から十分時間が経過した後, 図 8 に示す弾性平板上の 4 点で時刻歴応答を計測し, これらの応答に波動振幅 フィルタリング（Gabai and Bucher, 2009）を行うことで求めた．時刻歴応答は，前節と同様に画像解析で得た.

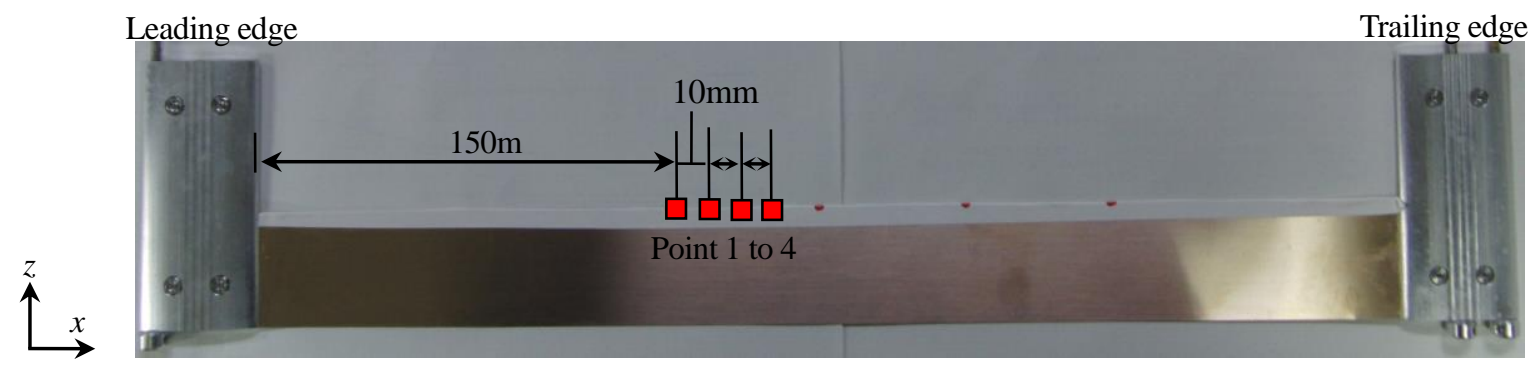

Fig. 8 Measurement points on the flexible plate for estimating Standing Wave Ratio(SWR). The steady state displacements at the points are measured by image analysis.

図 9 には，2Hz で駆動したときの弾性平板上の波動の様子を示す. 本図では，上段から下段に向けて $0.07 \mathrm{~s}$ ご とに撮影した写真を並べた。本図に赤丸で示した最大振幅点が，時間経過と共に図の左（前端）から右（後端） へ移動しており，進行波が支配的な状態を実現できていることがわかる. 


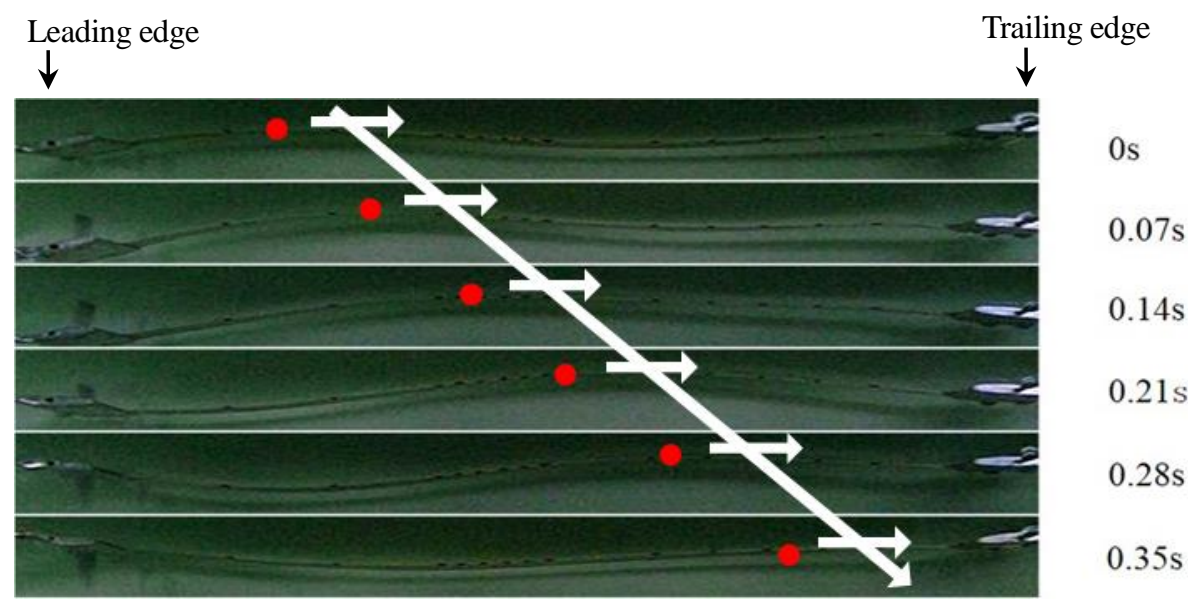

Fig. 9 Traveling wave on the aquatic flexible plate (driving frequency : $2 \mathrm{~Hz}$ ). The figure shows the wave travels from leading edge to trailing edge.

図 10 には，駆動周波数 $2 \mathrm{~Hz}$ の場合に，図 8 の Point1 から 4 で計測した変位を示す. 距離減衰の影響や, 完全 に抑制できなかった反射波の影響で Point 1 から 4 の変位振幅に変動が生じている. しかし, 正弦波状の波が Point1 から 4 へ進行している様子は観測でき，図 9 に示した結果からも進行波が支配的な状態であることがわかる.

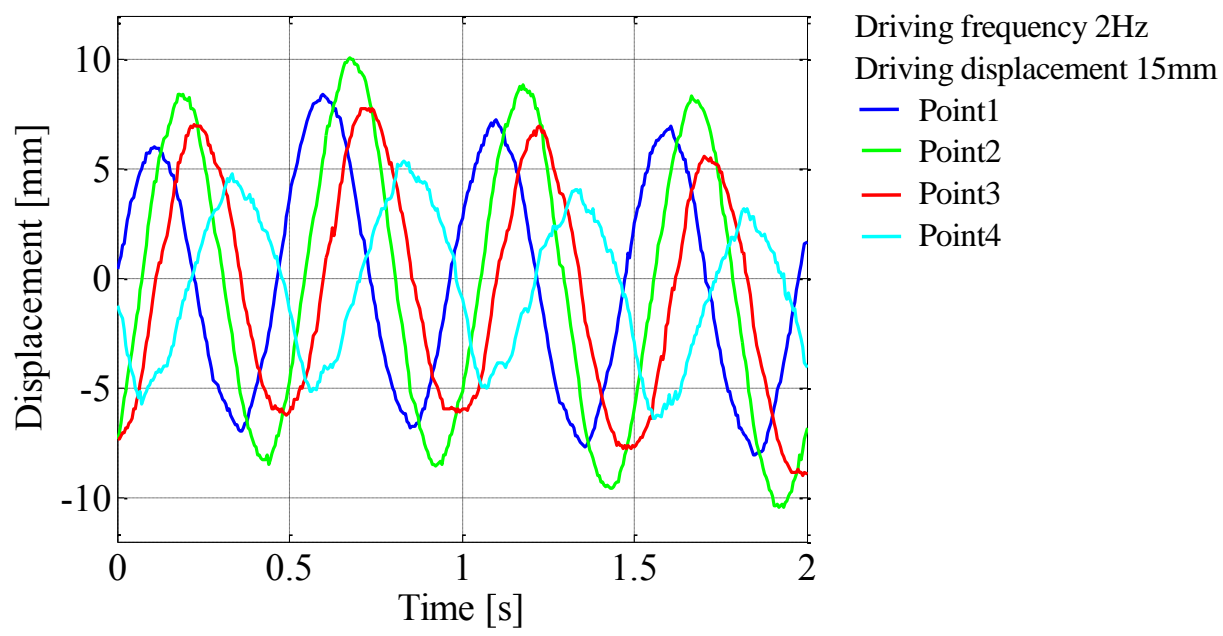

Fig. 10 Displacements at the four measurement points. The wave amplitude slightly changes at each point because of reflected wave and distance decay. However, the figure shows that traveling wave is dominant.

図 11 には, $1 \mathrm{~Hz}$ から $5 \mathrm{~Hz}$ まで $1 \mathrm{~Hz}$ 刻みの周波数において進行波生成駆動したときの定在波比を示す．実際に は，10Hz までの駆動条件で実験を行ったが，6Hz 以上では水面に波が立ち，画像計測ができなかったことから，

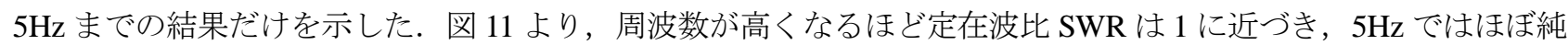
粋進行波とみなせる SWR=1.05 であった。この結果から, 式（15）と式（18）に従う駆動法と, 図 7 から求めた 波数を利用することにより，後端での反射が抑制され，実験においてもほぼ純粋な進行波を生成可能であること が確認できた. しかしながら, 周波数が低いほど定在波比が悪化する傾向があり，この原因は解明できていない. 図 7 の波数計測結果においても，低周波数ほど最小二乗近似の曲線と実験結果が乘離しているが，その理由は不 明である. 今後の課題として, 低速での推進効率を向上させるために, 低周波域での定在波比を改善することを 検討する必要がある. 


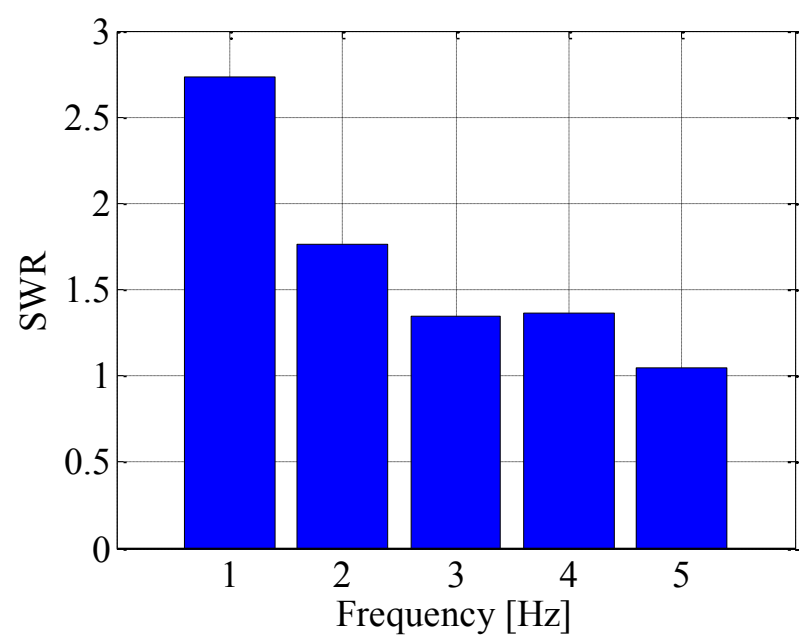

Fig. 11 Standing wave ratio (SWR) of the operational aquatic flexible plate. The figure shows that a quasi-pure traveling wave can be generated on the aquatic flexible plate by the proposed method for various frequencies, especially for high frequency range.

\section{5. 結 言}

本論文では, 少数のアクチュエータで進行波型水中推進機を実現させるため, 弾性平板の後端で生じる反射波 を抑制して純粋進行波を生成する手法を構築した. また，検証用の実験装置を製作し，検証を行った．本論文で 得られた知見を以下にまとめる.

(1) 矩形の弾性平板上に純粋な平面進行波を生成するために, リニアサーボアクチュエータによる強制変位で平 板の前端の変位と，後端の変位および回転角を与える手法を示した.

（2）平板上を伝播する平面進行波の位相速度を計測することで，付加質量効果を含めた形で，水中に置かれた弾 性平板上の曲げ波の波数を同定できた.

（3）この波数を用い，駆動周波数 $1 \mathrm{~Hz}$ から $5 \mathrm{~Hz}$ の駆動実験を行ったところ，定在波比 2.7 以下の進行波生成を実 現できた．特に，駆動周波数が $3 \mathrm{~Hz}$ から $5 \mathrm{~Hz}$ の範囲では，定在波比が 1.5 以下となり，ほぼ純粋な進行波を 生成できることを確認した，しかしながら，周波数が低いほど定在波比が悪化する傾向があり，この原因を 解明することが今後の課題として残された.

\section{謝 辞}

本研究の一部である波数同定および進行波生成技術については，JSPS 科研費 25420182 の助成を受けたもので ある.また，リニアサーボアクチュエータを用いた実験装置の製作については，公益財団法人 JKA の Ring ring project より 26JKA 機械第 76 号の助成を受けたものである. ここに記して謝意を表す.

\section{文献}

東昭，生物の動きの事典，朝倉書店 (1997), p. 141.

福田敏男, 細貝英実, 菊池勇, 形状記憶合金を用いた分布形アクチュエータとその水中移動メカニズムへの応用, 日本機械学會論文集. C 編, Vol. 56, No. 526 (1990), pp. 1475-1480.

Gabai, R. and Bucher, I., Excitation and sensing of multiple vibrating traveling waves in one-dimensional structures, Journal of Sound and Vibration, Vol. 319 (2009), pp. 406-425.

Hertel, H., Structure, form and movement (1967), Van Nost. Reinhold, U.S.

岩本宏之, 田中信雄, 柔軟はりにおける波動フィルタリング法に関する研究, 日本機械学会論文集 C 編, Vol.68,

No.675 (2002), pp.3246-3253. 
神部勉，動物の運動の流体力学，日本物理學會誌，Vol. 33, No.6 (1978)，pp. 484-497.

加藤直三, アクアバイオメカニズム研究の海洋工学への応用, 日本造船学会第 16 回海洋工学シンポジウム講演 論文集 (2001)，pp. 131-137.

小林俊一, 屈曲運動生物を模倣した水中推進機構の推進力特性, 日本機械学會論文集 B 編, Vol. 60 , No. 579(1994), pp. 3613-3617.

Mace, B. R., Wave reflection and transmission in beams, Journal of Sound and Vibration, Vol. 97, No. 2 (1984), pp. 237-246.

Sfakiotakis, M., Lane, D. M. and Davies, J. B. C., Review of fish swimming modes for aquatic locomotion, Journal of Oceanic Engineering, Vol. 24, No.2 (1999), pp. 237-252.

田中一郎, 永井實, 抵抗と推進の流体力学一水棲動物の高速遊泳能力に学ぶー, シップ・アンド・オーシャン財 団 (1996), pp. 80-88.

田中信雄, 菊島義弘, 柔軟ばりの曲げ波制御に関する研究: アクティブ・シンク法の提案, 日本機械学會論文集 C 編, Vol. 56, No.522 (1990), pp. 351-359.

戸田保幸, 屈曲型側ヒレ推進機構をもつ水中ロボットーイカロボット, 日本マリンエンジニアリング学会誌, Vol. 43, No. 4 (2008), pp. 557-561.

渡辺昌宏，林健一，村松功一，小林信之，酒井高章，柔軟な魚の尾ひれの運動をモデルにした弾性平板の進行波 的波動運動による推力特性，日本機械学會論文集 C 編，Vol. 67，No.655 (2001)，pp. 682-690.

山野彰夫, 新谷篤彦, 伊藤智博, 中川智皓, 形状記憶合金アクチュエータの非線形性を考慮した細管内泳動推進 体の駆動方法の最適化，日本機械学会論文集，Vol. 80，No. 813 (2014)，DOI: 10.1299/transjsme.2014dr0119.

\section{References}

Azuma, A., Encyclopedia of movement of organisms, Asakura Publishing (1997), p. 141(in Japanese).

Fukuda, T., Hosokai, H. and Kikuchi, I., Distributed type of actuators of shape memory alloy and its application to underwater mobile robotic mechanisms, Transactions of the JSME, Series C, Vol. 56, No. 526 (1990), pp. 1475-1480 (in Japanese).

Gabai, R. and Bucher, I., Excitation and sensing of multiple vibrating traveling waves in one-dimensional structures, Journal of Sound and Vibration, Vol. 319 (2009), pp. 406-425.

Hertel, H., Structure, form and movement (1967), Van Nost. Reinhold, U.S.

Iwamoto, H. and Tanaka, N., Wave filtering method for a flexible beam, Transactions of the JSME, Series C, Vol. 68, No. 675 (2002), pp.3246-3253(in Japanese).

Kambe, T., Fluid mechanics of animal locomotion, BUTSURI, Vol. 33, No.6 (1978), pp. 484-497(in Japanese).

Kato, N., Application of study on aqua bio-mechanisms to ocean engineering, 16th OCEAN ENGINEERING SYMPOSIUM (2001), pp. 131-137(in Japanese).

Kobayashi, S., Propulsion force characteristics of propulsion mechanism imitating bending-movement organisms in water, Transactions of the JSME, Series B, Vol. 60, No. 579 (1994), pp. 3613-3617(in Japanese).

Mace, B. R., Wave reflection and transmission in beams, Journal of Sound and Vibration, Vol. 97, No. 2 (1984), pp. 237 - 246.

Sfakiotakis, M., Lane, D. M. and Davies, J. B. C., Review of fish swimming modes for aquatic locomotion, IEEE Journal of Oceanic Engineering, Vol. 24, Issue 2 (1999), pp. 237-252.

Tanaka, I. and Nagai, H., Fluid dynamics of resistance and propulsion -Learn fast swimming ability of aquatic animal-, SHIP \& OCEAN FOUNDATION (1996) (in Japanese). pp. 80-88.

Tanaka, N. and Kikushima, Y., Flexural wave control of a flexible beam: proposition of the active sink method, Transactions of the JSME, Series C, Vol. 56, No.522 (1990), pp. 351-359(in Japanese).

Toda, Y., Aquatic vehicle with two undulating side fins: squid robot, Journal of the Japan Institution of Marine Engineering, Vol. 43, No. 4 (2008), pp. 557-561(in Japanese).

Watanabe, M., Hayashi, K., Muramatsu, K., Kobayashi, N. and Sakai, T., Propulsion force characteristics of traveling-wave motion of flexible plate modeled on flexible caudal fin of fish, Transactions of the JSME, Series C, Vol. 67, No.655 (2001), pp. 682-690(in Japanese).

Yamano, A., Shintani, A., Ito, T. and Nakagawa, C., Optimization on driving method of moving body in narrow passage considering nonlinearity of shape memory alloy actuator, Transactions of the JSME(in Japanese), Vol. 80, No. 813 (2014), DOI: 10.1299/transjsme.2014dr0119. 